dered by the Department of History and Archives; doubtless hundreds of other cases could be cited were the department desirous of publishing the facts. Therefore, it is with great appreciation of the value of this work, that I say "Keep the History and Archives and let the good work go on."

\title{
LOOKING TO RESTORATION OF PROSPERITY
}

Iowa representatives of industry have taken the initial steps to assure cooperation in the post-war task of restoring stability and prosperity by the processes that gave to the people of Iowa and the nation their present world leadership. A conference was held in Des Moines March 26, 1943, which may have great historic importance. This meeting was under the direction of Mr. Ralph Budd, who is regional chairman of the Committee for Economic Development, of which Mr. Paul G. Hoffman, of Indiana, is the national chairman. This committee is a voluntary group of business men formed "to assist commerce and industry in preparing to make their full contribution to stability and prosperity through high levels of employment and productivity when peace comes." The committee for Iowa was formed of some fifteen leading business men, with Herbert L. Horton, of Des Moines, as chairman.

The keynote of the conference was the duty of commerce and industry to assure the men in the armed forces that there will be work for them in a free society when the military job is finished, and that such assurance is vitally needed as a contribution to the morale of all concerned in the prosecution of the war.

Mr. Budd, who is president of the Burlington railroad, received his education in Des Moines, and takes special interest in Iowa affairs. All members of the committee are actively engaged in various lines of manufacturing and commerce and are large employers of working men. The plannng by and through this committee is one of the major Iowa activities incidental to the war. 
Copyright of Annals of Iowa is the property of State of Iowa, by \& through the State Historical Society of Iowa and its content may not be copied or emailed to multiple sites or posted to a listserv without the copyright holder's express written permission. However, users may print, download, or email articles for individual use. 